\title{
A new Saharan dust source activation frequency map derived from MSG-SEVIRI IR-channels
}

\author{
K. Schepanski, ${ }^{1,2}$ I. Tegen, ${ }^{1}$ B. Laurent, ${ }^{1}$ B. Heinold, ${ }^{1}$ and A. Macke ${ }^{2}$ \\ Received 27 March 2007; revised 27 June 2007; accepted 9 August 2007; published 19 September 2007.
}

[1] We present a new dust source area map for the Sahara and Sahel region, derived from the spatiotemporal variability of composite images of Meteosat Second Generation (MSG) using the 8.7, 10.8 and $12.0 \mu \mathrm{m}$ wavelength channels for March 2006-February 2007. Detected dust events have been compared to measured aerosol optical thickness (AOT) and horizontal visibility observations. Furthermore the monthly source area map has been compared with the Ozone Monitoring Instrument aerosol index (AI). A spatial shift of the derived frequency patterns and the local maxima of AI-values can be explained by wind-transport of airborne dust implicitly included in the AI signal. To illustrate the sensitivity of a regional model using the new dust source mask, we present a case study analysis that shows an improvement in reproducing aerosol optical thickness in comparison to the original dust source parameterization. Citation: Schepanski, K., I. Tegen, B. Laurent, B. Heinold, and A. Macke (2007), A new Saharan dust source activation frequency map derived from MSG-SEVIRI IRchannels, Geophys. Res. Lett., 34, L18803, doi:10.1029/ 2007GL030168.

\section{Introduction}

[2] Soil dust aerosol plays an important role in the climate system [Intergovernmental Panel on Climate Change, 2007]. Dust impacts the atmospheric radiation budget indirectly by influencing microphysical cloud processes and directly by scattering and absorbing shortwave radiation, and absorbing and re-emitting longwave radiation [Sokolik et al., 2001]. Furthermore, dust deposition provides nutrients for oceanic microorganisms, ultimately influencing the $\mathrm{CO}_{2}$-cycle [e.g., Jickells et al., 2005]. The atmospheric dust distribution itself is influenced by climate parameters like wind fields and precipitation.

[3] The magnitude of the dust effects depends on the chemical, physical and optical properties of the particles, which vary due to different source areas and transport paths [e.g., Koven and Fung, 2006]. An adequate description of source areas is a prerequisite for estimates of the effects of dust aerosol, as well as for understanding the response of dust emissions to changing climate conditions.

[4] Satellite remote sensing has previously been used to obtain information on dust sources. Daily maps of an absorbing aerosol index (AI), which is an indicator for the presence of dust aerosol over deserts, have been calculated from radiance measurements of the Total Ozone Mapping

\footnotetext{
${ }^{1}$ Leibniz Institute for Tropospheric Research, Leipzig, Germany.

${ }^{2}$ Leibniz Institute of Marine Sciences, IFM-GEOMAR, Kiel, Germany.
}

Copyright 2007 by the American Geophysical Union. 0094-8276/07/2007GL030168\$05.00
Spectrometer (TOMS) [Herman et al., 1997], and since September 2004 from the Ozone Monitoring Instrument (OMI) [Levelt, 2002]. Regions of maximum AI or high frequency of high AI occurrences are widely used as a proxy for dust source areas [e.g., Prospero et al., 2002]. Recent applications in modeling the atmospheric dust cycle made use of the fact that the locations of maximum AI agree well with enclosed topographic depressions, and parameterize those as preferential dust sources [Ginoux et al., 2001; Tegen et al., 2002; Zender and Newman, 2003].

[5] Beside the AI, a retrieval for aerosol properties over bright-reflecting surfaces exists considering the blue part of the shortwave spectrum ("Deep Blue" algorithm; [Hsu et al., 2004]) using measurements by Sea-viewing Wide Fieldof-view Sensor (SeaWiFS) and Moderate Resolution Imaging Spectroradiometer (MODIS). Furthermore a daily noontime Infrared Difference Dust Index (IDDI) derived from Meteosat 1 has been used to detect dust source areas [Brooks and Legrand, 2000]. All of these indices that provide information about aerosol over land are available at daily time resolution and do not resolve sub-daily processes like the daily cycle of dust emission.

[6] Here we use the Meteosat Second Generation (MSG) Spinning Enhanced Visible and InfraRed Imager (SEVIRI) thermal IR radiances to identify dust source areas in the Sahara and Sahel region for applications in large-scale dust emission and transport models, making use of the high temporal and spatial resolution of the SEVIRI data [Schmetz et al., 2002].

\section{Satellite Based Dust Retrieval From MSG}

[7] Atmospheric dust can be detected by MSG during daytime and nighttime at high temporal and spatial resolutions using IR wavelength channels. Here, the brightness temperature (BT) is used, and is calculated from narrowband radiances measured by the SEVIRI instrument onboard the geostationary MSG satellite located at $3.5^{\circ} \mathrm{W}$ above the equator. With a sampling rate of 15 minutes and a spatial resolution of $3 \mathrm{~km}$ at nadir, SEVIRI BT are available at a high spatiotemporal resolution, which we use to identify activated dust sources (see Schmetz et al. [2002] for a detailed description of the SEVIRI instrument).

[8] EUMETSAT offers a dust index product for MSG scenes on its website based on BT differences (BTD) (http:// www.eumetsat.int). The same BTD and composite picture configuration is used for dust detection in this work. It is composed of the BTD at $12.0 \mu \mathrm{m}-10.8 \mu \mathrm{m}$ and $10.8 \mu \mathrm{m}-$ $8.7 \mu \mathrm{m}$, as well as $10.8 \mu \mathrm{m}$ [e.g., Ackerman, 1997; Sokolik, 2002]. Several effects lead to dust detection in the thermal IR spectrum [Ackerman, 1997]. The thermal emissivity of desert surface is low in the $8.7 \mu \mathrm{m}$ wavelength band 
compared to the $10.8 \mu \mathrm{m}$ wavelength band. Compared to clear sky conditions dust decreases the BTD between the $10.8 \mu \mathrm{m}$ and $12.0 \mu \mathrm{m}$ wavelength bands $(\operatorname{BTD}(12,10.8))$, as it does for the $8.7 \mu \mathrm{m}$ and $10.8 \mu \mathrm{m}$ wavelength bands $(\operatorname{BTD}(10.8,8.7))$.

[9] According to Wald et al. [1998], thermal emissivities at the considered $\operatorname{BTD}(10.8,8.7)$ is more dependent on particle size than on temperature due to the opposite emissivity dependencies on particle size. A decrease in BTD for a dust loaded atmosphere in comparison to clearsky conditions is also found in the $\operatorname{BTD}(12,10.8)$ [Ackerman, 1997; Sokolik, 2002].

[10] Over dark surfaces (e.g. ocean) dust plumes can be clearly detected at visible wavelengths. Here, the BTD composite has been compared to the visible radiances that were showing enhanced reflection due to the presence of dust aerosols. In each case we detected co-location of the visible and IR detected aerosol plumes. Spatial correlations between $\operatorname{BTD}(12,10.8)$ resp. $\operatorname{BTD}(10.8,8.7)$ and radiances measured at $0.6 \mu \mathrm{m}$ for a $50 \times 50$-pixel offshore area on March 07, 2006 show a high dust pattern agreement (correlation coefficient of $|\mathrm{r}|=0.79$ resp. $|\mathrm{r}|=0.85$ ) for March 2006. Furthermore dust source activation occurs for some regions with a high frequency per month at nearly the same time of the day (e.g. in the Bodele Depression in December 2006 at 17 days at 7-9 am). For the case when the temperature of the surroundings is approximately constant, the regularity of dust emission for a known strong dust source [Prospero et al., 2002] shows that the IR dust index used here indicates the presence of airborne dust.

[11] To further evaluate the MSG dust index as an indicator for the presence of airborne dust, we perform correlations with aerosol optical thickness (AOT) sunphotometer measurements for some AErosol RObotic NETwork (AERONET) [Holben et al., 1998] stations. To ensure that only the AOT affected by mineral dust are considered, we only use retrievals for AOT $(1020 \mathrm{~nm}) \geq 0.3$ and Angstroem coefficient $\alpha \leq 0.6$ [Dubovik et al., 2002]. The MSG dust index is dominated by the $\operatorname{BTD}(12,10.8)$ signal. Peaking $\operatorname{BTD}(12,10.8)$ values and measured AOT show high correlations (Banizoumbou $|\mathrm{r}|=0.73$, Cinzana $|\mathrm{r}|$ $=0.63$ and Dakar $|r|=0.55)$. Furthermore correlations between the dust indicating composite color and measured AOT for significant dust events (AOT $\geq 1$ ) have been computed for March 2006: Banizoumbou $|r|=0.77$, Cinzana $|\mathrm{r}|=0.70$, and Dakar $|\mathrm{r}|=0.66$.

[12] MSG observed dust source activation events have also been compared to reduced horizontal visibility recorded at the WMO stations Faya-Largeau $\left(17^{\circ} 56^{\prime} \mathrm{N}\right.$; $\left.19^{\circ} 08^{\prime} \mathrm{E}\right)$, Abeche $\left(13^{\circ} 51^{\prime} \mathrm{N} ; 20^{\circ} 51^{\prime} \mathrm{E}\right)$, Bilma $\left(18^{\circ} 41^{\prime} \mathrm{N}\right.$; $\left.12^{\circ} 55^{\prime} \mathrm{E}\right)$, Nguigmi $\left(14^{\circ} 15^{\prime} \mathrm{N} ; 13^{\circ} 07^{\prime} \mathrm{E}\right)$, Agadez $\left(16^{\circ} 58^{\prime} \mathrm{N}\right.$; $\left.7^{\circ} 59^{\prime} \mathrm{E}\right)$, Zinder $\left(13^{\circ} 47^{\prime} \mathrm{N} ; 8^{\circ} 59^{\prime} \mathrm{E}\right)$ for the area $\left(13-20^{\circ} \mathrm{N}\right.$; $\left.5-23^{\circ} \mathrm{E}\right)$ during March 2006 to February 2007. For the station observations, a dust event is defined for visibility below $5000 \mathrm{~m}$ [Mahowald et al., 2007], occurring at least once a day at one of the stations. Major dust events are well marked in both data sets. For the whole area, $68.7 \%$ of the time both MSG and station observations agree in indicating the presence or absence of dust events. Taking into account a one-day delay caused by the distance between dust source and station location, the agreement between MSG- and station observations reaches $74.9 \%$.
[13] Those tests support the premise that the MSG index shows the presence of dust. We do not attempt to derive quantitative optical thickness information from that index. Composite pictures using the $\operatorname{BTD}(12,10.8), \operatorname{BTD}(10.8,8.7)$ and BT(10.8) are calculated for March 2006 to February 2007 for each 15-min SEVIRI scan. (On www.eumetsat.int/ Home/Main/Image_Gallery/Satellite_Images_of_the Month/Gallery/index.htm?l=en a video animation of the March 05-March 8, 2006 dust event can be found.) Because of the high spatiotemporal resolution, dust source activation can be observed and localized by visual detection of tracing dust plume patterns back to their origin, in particular by inspecting consecutive images during dust mobilization and transport events. Dust emitting areas are visually determined and marked as dust source activation event on a $1^{\circ} \times 1^{\circ}$ gridded map for the Saharan region between $5^{\circ} \mathrm{N} ; 20^{\circ} \mathrm{W}$ and $40^{\circ} \mathrm{N} ; 40^{\circ} \mathrm{E}$. The monthly frequency of source activation events is calculated for each grid cell.

\section{MSG Derived Dust Source Activation Frequency Map}

[14] For the one year of analyzed data, the retrieved spatial dust source activation frequency (DSAF) pattern change with the seasons (Figure 1). The main source areas agree with source areas described by D'Almeida [1986] and Prospero et al. [2002]. During December-February, the areas of most frequent dust emission events are located in the south-easterly part of the Sahara, mainly the Bodele Depression $\left(16-19^{\circ} \mathrm{N} ; 16-19^{\circ} \mathrm{E}\right)$, where activation occurs at up to $65 \%$ of all days. The second most frequent source activation in this season is located in the southern foothills of Massif l'Air $\left(15-18^{\circ} \mathrm{N} ; 5-9^{\circ} \mathrm{E}\right)$ with dust activations of up to $41 \%$ of days. During summer (June-August), dust is most frequently emitted in the western foothills of the Red Sea Mountains $\left(16-19^{\circ} \mathrm{N} ; 34-36^{\circ} \mathrm{E}\right.$ ) (up to $27 \%$ of days), the foothills around Massif $1^{\prime} \operatorname{Air}\left(17-20^{\circ} \mathrm{N} ; 6-8^{\circ} \mathrm{E}\right.$ ) (up to $26 \%$ of days), the area westerly of the Adrar Mountains $\left(20-21^{\circ} \mathrm{N} ; 1-0^{\circ} \mathrm{W}\right)$ (up to $25 \%$ of days) and in the area of Sebkhas Mekherrane and Azzel Matti $\left(25-27^{\circ} \mathrm{N} ; 0-3^{\circ} \mathrm{E}\right)$ (up to $20 \%$ of days). The temporal satellite observations indicate that catabatic flows like morning mountain winds and strong surface winds forced by convective clouds (squall lines), especially during the summer time in the Sahel region, are likely important for activating dust sources [Engelstaedter and Washington, 2007]. Dust activation in the vicinity of mountainous areas occurs mostly during mornings and during afternoons and early evenings for dust events caused by strong winds in connection with convective clouds. Furthermore, the regional sea-land-wind circulation may activate dust sources in the north-eastern part of Libya. Seasonal changes in meteorological conditions cause changes in the spatial pattern of dust source activation.

\section{Comparison of the MSG Derived Dust Source Areas to OMI Aerosol Index}

[15] A comparison of the new DSAF map derived from MSG with the OMI AI for the same period (here: July 2006) indicates that the maxima in AI retrievals are shifted downwind of the MSG derived source distribution 
December 2006, January and February 2007

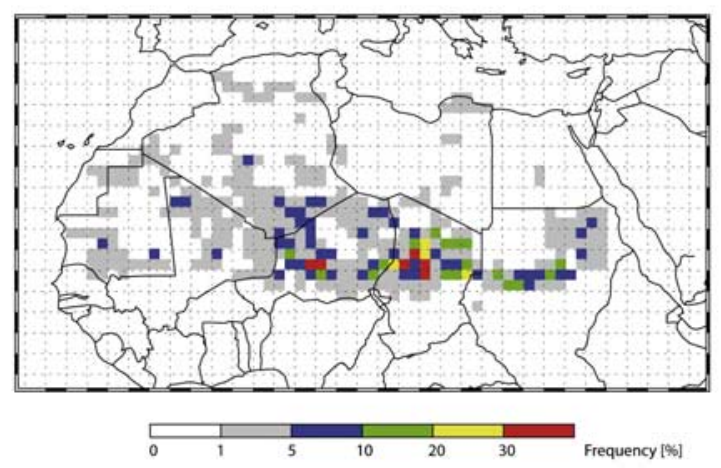

June, July and August 2006

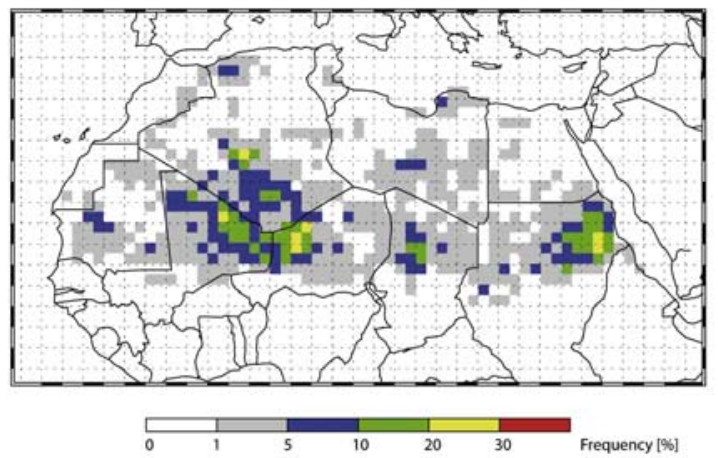

March, April and May 2006

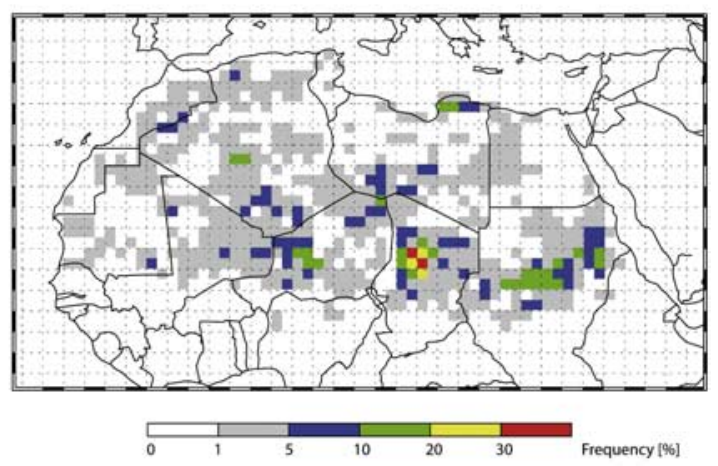

September, October and November 2006

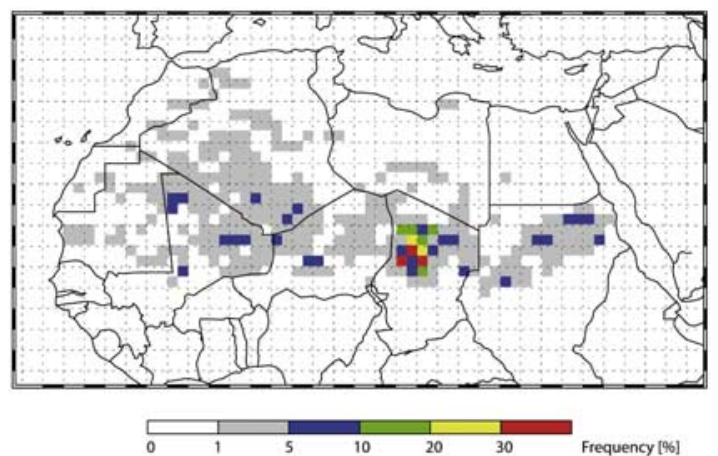

Figure 1. Seasonal frequencies of dust source activation on a $1^{\circ} \times 1^{\circ}$ grid, derived from MSG IR difference composite images for March 2006 to February 2007.

(Figure 2). AI values have previously been used as proxy for dust source areas [Prospero et al., 2002] and are available for each day. The regional shift between the patterns in the two data sets can be explained by the lower sampling rate of AI. OMI has its sun-synchronous overpass over the equator at 13:45 local time [Levelt, 2002], but most dust sources are activated during the morning hours or during the afternoons and evenings (gusts in connection with convective clouds). Thus, at the OMI overpass time, the airborne dust has already been mixed up into the atmosphere and transported by local and regional wind systems, thus probably causing a bias in the OMI-retrieved source locations. Furthermore, dust AI retrieval below $1.5 \mathrm{~km}$ height is difficult [Herman et al., 1997], so that mineral dust in proximity to its source may not be detected. Both effects result in a transport bias affecting the AI data set when used as proxy for dust source determination, where in each case the differences between the present MSG results and the AI can be explained by downwind transport of the dust plumes at the time of the AI retrieval.

\section{Model Application}

[16] While computations of the dependencies of dust emission fluxes on soil, surface properties, and friction wind velocity is meanwhile quite sophisticated in large-scale models [e.g., Marticorena et al., 1997], the accuracy of such computations is limited by the available input data. The Saharan DSAF map provides a new mask for potential dust source areas useful for models of the Saharan dust cycle. a)

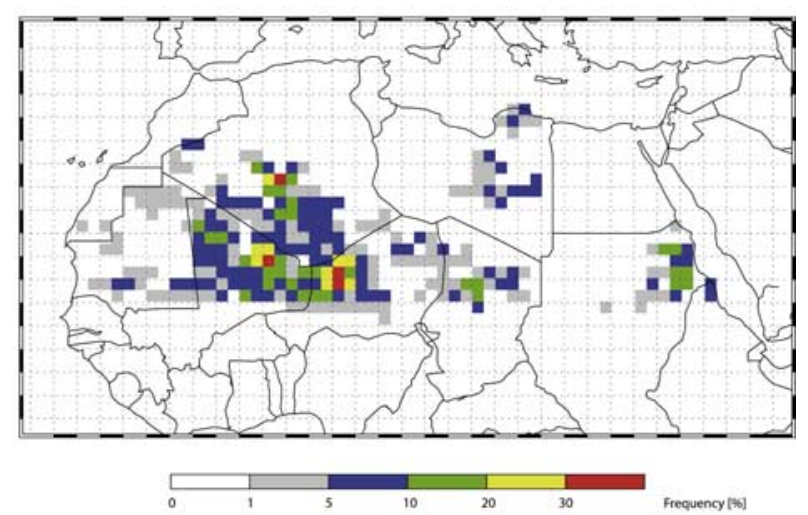

b)

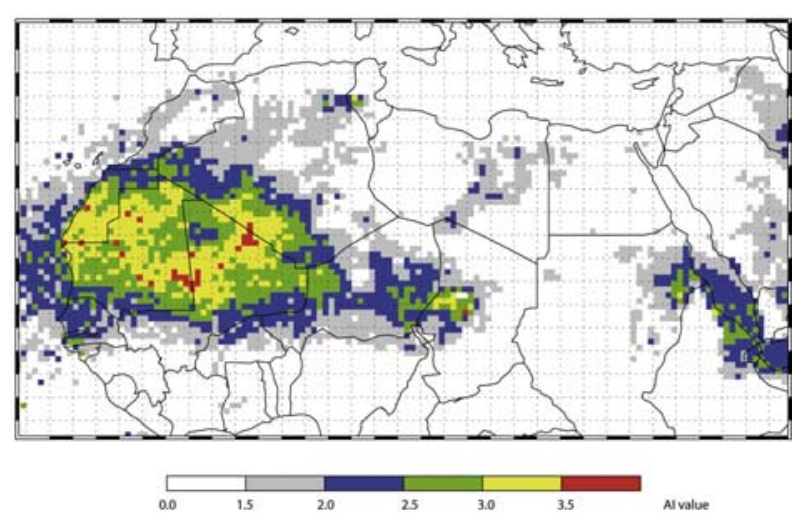

Figure 2. Monthly frequency of dust source activation for July 2006, derived from (a) MSG IR composite pictures and (b) averaged OMI AI for July 2006. 
a)

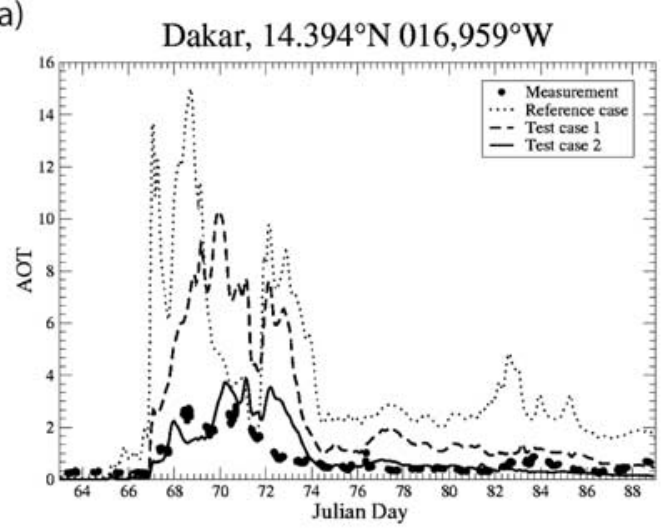

c)

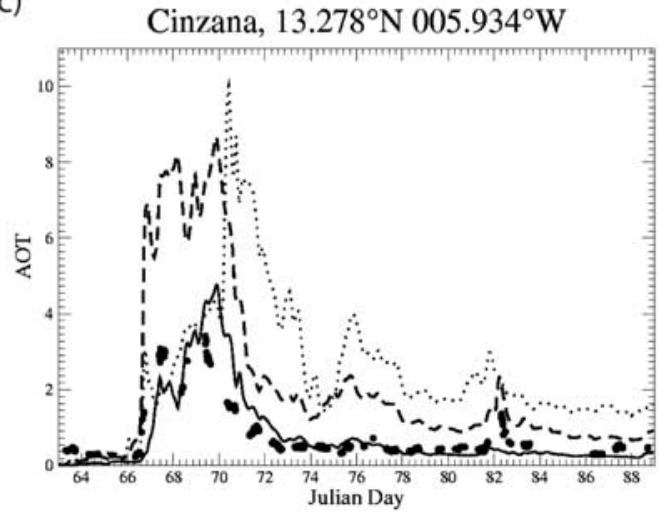

b)

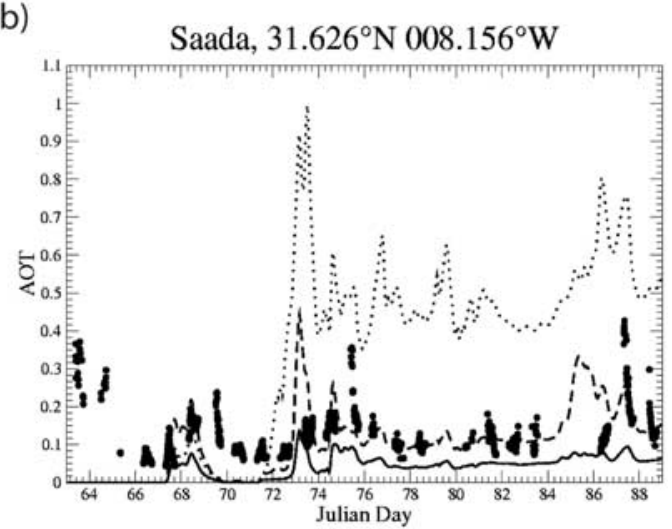

d)

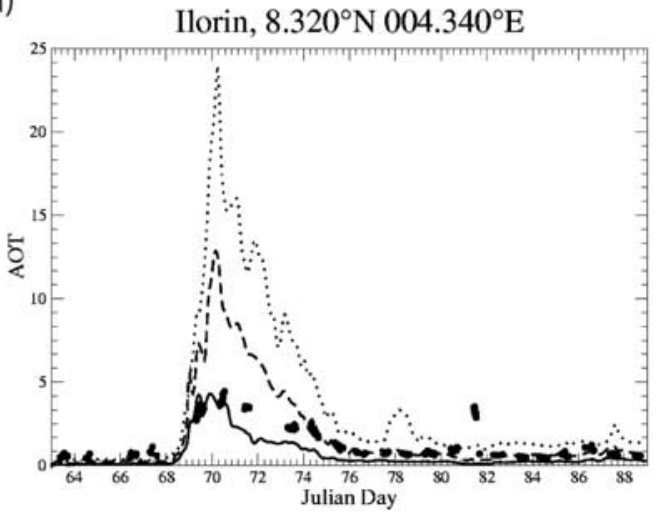

Figure 3. Comparison of modeled $(550 \mathrm{~nm})$ and measured AOT(440 nm) at AERONET stations for (a) Dakar, (b) Saada, (c) Cinzana and (d) Ilorin for March 4th-29th 2006 (shown as Julian Days).

[17] We use the new source area map as input field for the LM-MUSCAT regional dust transport model [Heinold et al., 2007] to test how using the new sources changes the model results for a case study of a Saharan dust event from March 5-10, 2006. The model consists of the regional meteorological model Lokal-Modell (LM) from the Deutscher Wetterdienst (DWD) and the MUlti-Scale Chemical Aerosol Transport Model (MUSCAT), including a dust emission scheme based on work by Tegen et al. [2002]. The model simulations were performed for an area covering $0.2^{\circ} \mathrm{N} ; 32.3^{\circ} \mathrm{W}-41.3^{\circ} \mathrm{N} ; 33.3^{\circ} \mathrm{E}$ with a horizontal resolution of $28 \mathrm{~km}$ and 40 vertical layers.

[18] For a first test, dust emission was set to zero at those grid cells where source activation was observed less than 4 times a year in the MSG data set. For Test case 1, soil texture was held at fixed values and the surface roughness was set to $z_{0}=0.001 \mathrm{~cm}$ for the entire model region. For Test case 2 the surface roughnesses used as input parameters in the dust emission code were set to satellite-derived values [Laurent et al., 2005]. The source activation and the magnitudes of emission fluxes are computed by LM-MUSCAT with the use of LM surface winds at each $80 \mathrm{~s}$ time step. A simulation of the same period with the original model [Heinold et al., 2007] was used as reference case. In the reference case, dust emission fluxes depend on soil texture, surface roughness, and surface wind speeds and topographic depressions are parameterized as hot spots of dust emission. Compared to AERONET's AOT the use of the new source area map clearly improves the modeled
AOT for both test cases compared to the reference case, both in AOT magnitude and timing of dust events (Figure 3 ). At the location of the AERONET station Saada the AOT results of Test case 1 show best agreement with the observations, while at the other stations Test case 2 performs best. Correlations between modeled and observed AOT show high correlation coefficients for the Test cases 1 and $2(|\mathrm{r}|=0.9)$ and lower ones for the reference case $(|\mathrm{r}|=0.7)$.

[19] These results using the new source area map as a mask for potential dust sources represent a first test; further refinements of the source formulation are needed. However, for this case study the implementation of the new derived dust source areas already show a promising improvement of the model performance.

\section{Summary and Conclusion}

[20] We used three thermal IR wavelength channels of the SEVIRI instrument on board the geostationary MSG satellite to detect the present atmospheric dust over land. The high spatiotemporal resolution makes the detection of individual dust emission events possible. Using this information we compiled a new monthly $1^{\circ} \times 1^{\circ}$ DSAF map for the Sahara and Sahel region from MSG IR composite pictures for the March 2006-February 2007. The advantage of using measurements by a geostationary satellite is the improved detection of atmospheric dust close to its source due to the higher temporal resolution of the retrievals compared to daily retrievals from polar-orbiting instruments 
like OMI. In the presence of clouds, localization of dust emission is limited. Uncertainties in localization and misinterpretation of the MSG-signal are the main error sources. Results from the application of the DSAF map as a 'mask' to describe dust emission areas in a dust model indicate that this observation-based dust source distribution has the potential to improve the performance of regional scale Saharan dust transport models compared to earlier source area parameterizations.

[21] The MSG data set will be extended to include results for upcoming years, and additional case studies will be performed to test possible improvements in dust models from the use of the new source parameterization.

[22] Acknowledgments. We acknowledge to the GES-DISC Interactive Online Visualization ANd aNalysis Infrastructure (Giovanni) as part of the NASA's Goddard Earth Science (GES) Data and Information Service Center (DISC) for the OMI AI data set. We thank B. Chatenet, B. Duchemin, B. Mougenot, R. Pinker and D. Tanre, for kindly providing AERONET data. We also thank the Deutscher Wetterdienst for good cooperation and support. We thank Natalie Mahowald and one anonymous reviewer for their comments, which helped to improve the paper.

\section{References}

Ackerman, S. A. (1997), Remote sensing aerosol using satellite infrared observations, J. Geophys. Res., 102(D14), 17,069-17,079.

Brooks, N., and M. Legrand (2000), Dust variability over northern Africa and rainfall in the Sahel, in Linking Climate Change to Landsurface Change, edited by S. J. McLaren and D. Kniveton, pp. 1-25, Kluwer Acad., Dordecht, Netherlands.

D'Almeida, G. A. (1986), A model for Saharan dust transport, J. Clim. Appl. Meteorol., 25, 903-916.

Dubovik, O., B. Holben, T. F. Eck, A. Smirnov, Y. J. Kaufman, M. D. King, D. Tanre, and I. Slutsker (2002), Variability of absorption and optical properties of key aerosol types observed in worldwide locations, J. Atmos. Sci., 59, 590-608.

Engelstaedter, S., and R. Washington (2007), Atmospheric controls on the annual cycle of North African dust, J. Geophys. Res., 112, D03103, doi:10.1029/2006JD007195.

Ginoux, P., M. Chin, I. Tegen, J. M. Prospero, B. Holben, O. Dubovik, and S.-J. Lin (2001), Sources and distributions of dust aerosols simulated with the GOCART model, J. Geophys. Res., 106(D17), 20,255-20,273.

Heinold, B., J. Helmert, O. Hellmuth, R. Wolke, A. Ansmann, B. Marticorena, B. Laurent, and I. Tegen (2007), Regional modeling of Saharan dust events using LM-MUSCAT: Model description and case studies, J. Geophys. Res., 112, D11204, doi:10.1029/2006JD007443.

Herman, J. R., P. K. Bhartia, O. Torres, C. Hsu, C. Seftor, and E. Celarier (1997), Global distribution of UV-absorbing aerosols from Nimbus 7/TOMS data, J. Geophys. Res., 102(D14), 16,911-16,922.

Holben, B. N., et al. (1998), AERONET-A federated instrument network and data archive for aerosol characterization, Remote Sens. Environ., 66, $1-16$.
Hsu, N. C., S. C. Tsay, M. D. King, and J. R. Herman (2004), Aerosol properties over bright-reflecting source regions, IEEE Trans. Geosci. Remote Sens., 42(3), 557-569.

Intergovernmental Panel on Climate Change (2007), Climate Change 2007: The Physical Science Basis., Contribution of Working Group I to the Forth Assessment Report of the Intergovernmental Panel on Climate Change, edited by S. Solomon et al., Cambridge Univ. Press, New York.

Jickells, T. D., et al. (2005), Global iron connections between desert dust, ocean biogeochemistry, and climate, Science, 308(5718), 67-71.

Koven, C. D., and I. Fung (2006), Inferring dust composition form wavelength-dependent absorption in Aerosol Robotic Network (AERONET) data, J. Geophys. Res., 111, D14205, doi:10.1029/2005JD006678.

Laurent, B., B. Marticorena, G. Bergametti, P. Chazette, F. Maignan, and C. Schmechtig (2005), Simulation of the mineral dust emission frequencies from desert areas of China and Mongolia using an aerodynamic roughness length map derived from POLDER/ADEOS 1 surface products, J. Geophys. Res., 110, D18S04, doi:10.1029/2004JD005013.

Levelt, R. F. (2002), OMI algorithm theoretical basis document volume 1: OMI Instrument, Level 0-1b processor, calibration \& operations, technical report, NASA Goddard Space Flight Cent., Greenbelt, Md.

Mahowald, N. M., J. A. Ballantine, J. Feddema, and N. Ramankutty (2007), Global trends in visibility: Implications for dust sources, Atmos. Chem. Phys., 7, 3309-3339.

Marticorena, B., G. Bergametti, B. Aumont, Y. Callot, C. N'Doume, and M. Legrand (1997), Modeling the atmospheric dust cycle: 2 . Simulation of Saharan dust sources, J. Geophys. Res., 102(D4), 4387-4404.

Prospero, J. M., P. Ginoux, O. Torres, S. E. Nicholson, and T. E. Gill (2002), Environmental characterization of global sources of atmospheric soil dust identified with the NIMBUS 7 Total Ozone Mapping Spectrometer (TOMS) absorbing aerosol product, Rev. Geophys., 40(1), 1002, doi:10.1029/2000RG000095

Schmetz, J., P. Pili, S. Tjemkes, D. Just, J. Kerkmann, S. Rota, and A. Ratier (2002), An introduction to Meteosat Second Generation (MSG), Bull. Am Meteorol. Soc., 83, 977-992.

Sokolik, I. N. (2002), The spectral radiative signature of wind-blown mineral dust: Implications for remote sensing in the thermal IR region, Geophys. Res. Lett., 29(24), 2154, doi:10.1029/2002GL015910.

Sokolik, I. N., D. M. Winker, G. Bergametti, D. A. Gillette, G. Carmichael, Y. J. Kaufman, L. Gomes, L. Schuetz, and J. E. Penner (2001), Introduction to special section: Outstanding problems in quantifying the radiative impacts of mineral dust, J. Geophys. Res., 106(D16), 18,015-18,027.

Tegen, I., S. P. Harrison, K. Kohfeld, and I. C. Prentice (2002), Impact of vegetation and preferential source areas on global dust aerosol: Results from a model study, J. Geophys. Res., 107(D21), 4576, doi:10.1029/ 2001JD000963.

Wald, A. E., Y. J. Kaufman, D. Tanre, and B.-C. Gao (1998), Daytime and nighttime detection of mineral dust over desert using infrared spectral contrast, J. Geophys. Res., 103(D24), 32,307-32,313.

Zender, C. S., and D. Newman (2003), Spatial heterogeneity in aeolian erodibility: Uniform, topographic, geomorphic, and hydrologic hypotheses, J. Geophys. Res., 108(D17), 4543, doi:10.1029/2002JD003039.

B. Heinold, B. Laurent, K. Schepanski, and I. Tegen, Leibniz Institute for Tropospheric Research, Permoser Straße 15, D-04318 Leipzig, Germany. (kerstin.schepanski@tropos.de)

A. Macke, Leibniz Institute of Marine Sciences, IFM-GEOMAR, Düsternbrooker Weg 20, D-2405 Kiel, Germany. 